\title{
A Case Report of Scrotal Squamous Cell Carcinoma Secondary to Chronic Urinary Irritation
}

Mohamed Ali Essid ${ }^{1}$, Abderrazak Bouzouita ${ }^{1}$, Ahmed Saadi ${ }^{1}$, Ahlem Blel ${ }^{2}$, Kays Chaker $^{3}$, Marouen Chakroun ${ }^{1}$, Haroun Ayed ${ }^{1}$, Mohamed Cherif ${ }^{1}$, Soumaya Rammah ${ }^{2}$, Mohamed Riadh Ben Slama ${ }^{1}$, Amine Derouiche ${ }^{1}$, Mohamed Chebil ${ }^{1}$

1. Urology, Charles Nicolle Hospital 2. Pathology, Charles Nicolle Hospital 3. Urology, La Rabta Hospital, Tunis, TUN

$\square$ Corresponding author: Mohamed Ali Essid, docdali86@gmail.com Disclosures can be found in Additional Information at the end of the article

\section{Abstract}

Most scrotum cancers are associated with occupational exposure. We report a case of a squamous cell carcinoma of the scrotum in a patient with a proximal meatus, secondary to mistreated urethral stricture. Based on our observations in this case, we think that chronic urinary inflammation of the scrotal skin may also be considered as a risk factor of scrotal cancer.

Categories: Dermatology, Urology, Oncology

Keywords: scrotal cancer, squamous cell carcinoma, hypospadias

\section{Introduction}

Scrotal cancer is very rare nowadays. In the past, occupational exposure has been associated with increased risk. With the improvement of working conditions, risk factors have changed. We present here a case report of scrotal cancer caused by urinary chronic irritation.

\section{Case Presentation}

We present an 83-year-old male patient, a retired greengrocer, with a long history of anterior urethral stricture treated endoscopically in the early 90's. Later, the patient ended up with a meatus on the penoscrotal junction. He was lost until 2015 when he consulted for a 16month history of an ulcerated lesion of the scrotum. He urinates from the same meatus, in a sitting position, and voided urine had always wet the scrotal skin. Meanwhile, he didn't receive

Received 03/19/2018 Review began 03/20/2018 Review ended 04/04/2018 Published 04/05/2018

\section{(๑) Copyright 2018}

Essid et al. This is an open access article distributed under the terms of the Creative Commons Attribution License CC-BY 3.0., which permits unrestricted use, distribution, and reproduction in any medium, provided the original author and source are credited. further treatment. Physical examination found a 4 x $2 \mathrm{~cm}$ ulcero-budding lesion on the median raphe with a depth of 10-15 $\mathrm{mm}$ and spreading a urine odor (Figure 1). 


\section{Cureus}

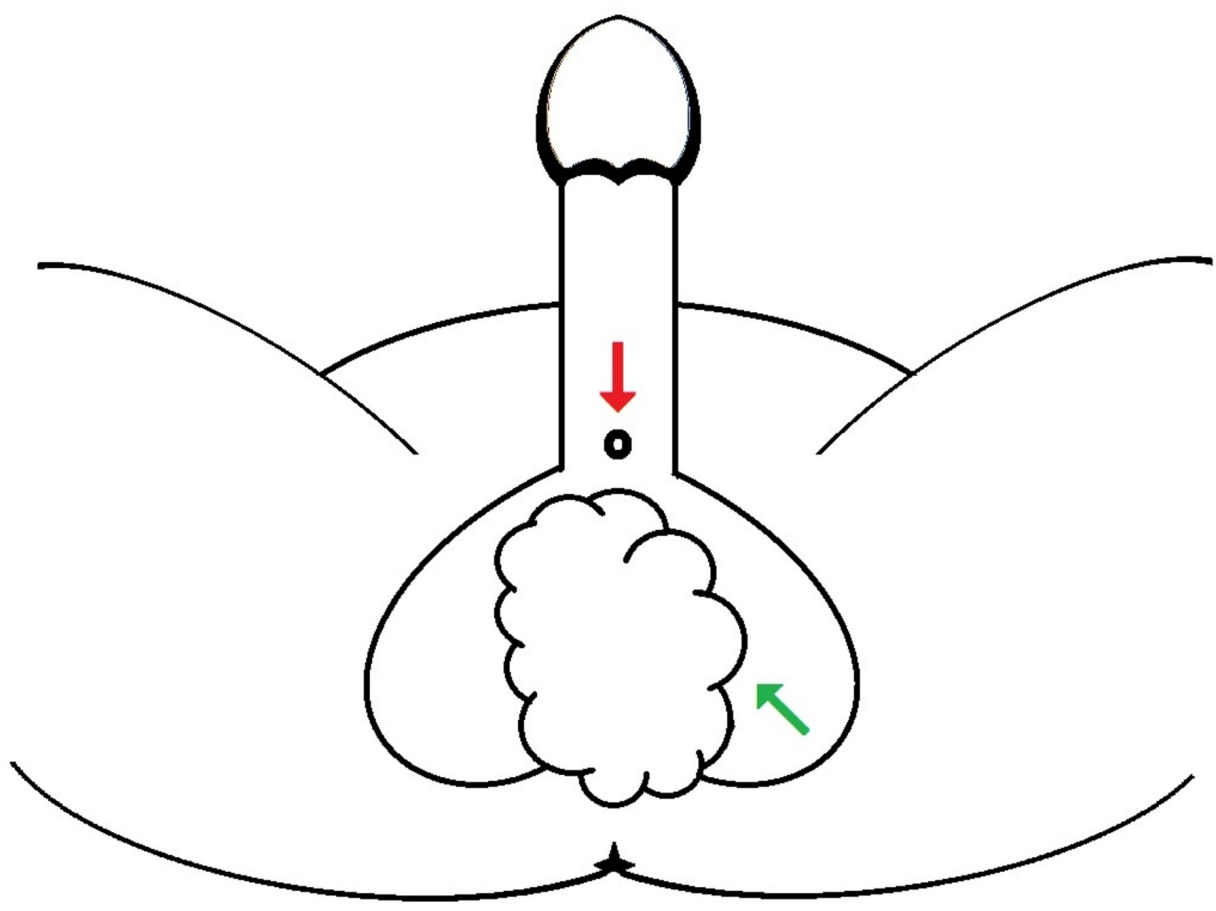

FIGURE 1: Sketch of the proximal urethral meatus (red arrow) and the scrotal lesion (green arrow) as present in our patient.

There were also bilateral inguinal indurate and painless nodes measuring $2-3 \mathrm{~cm}$. No particularity on the testis exam and rectal touch. Apical meatus was closed. A biopsy of the lesion found a moderately differentiated squamous cell carcinoma. A thoraco-abdominopelvic computed tomography (CT) scan showed bilateral inguinal and iliac nodes and no metastasis (Figure 2). 


\section{Cureus}

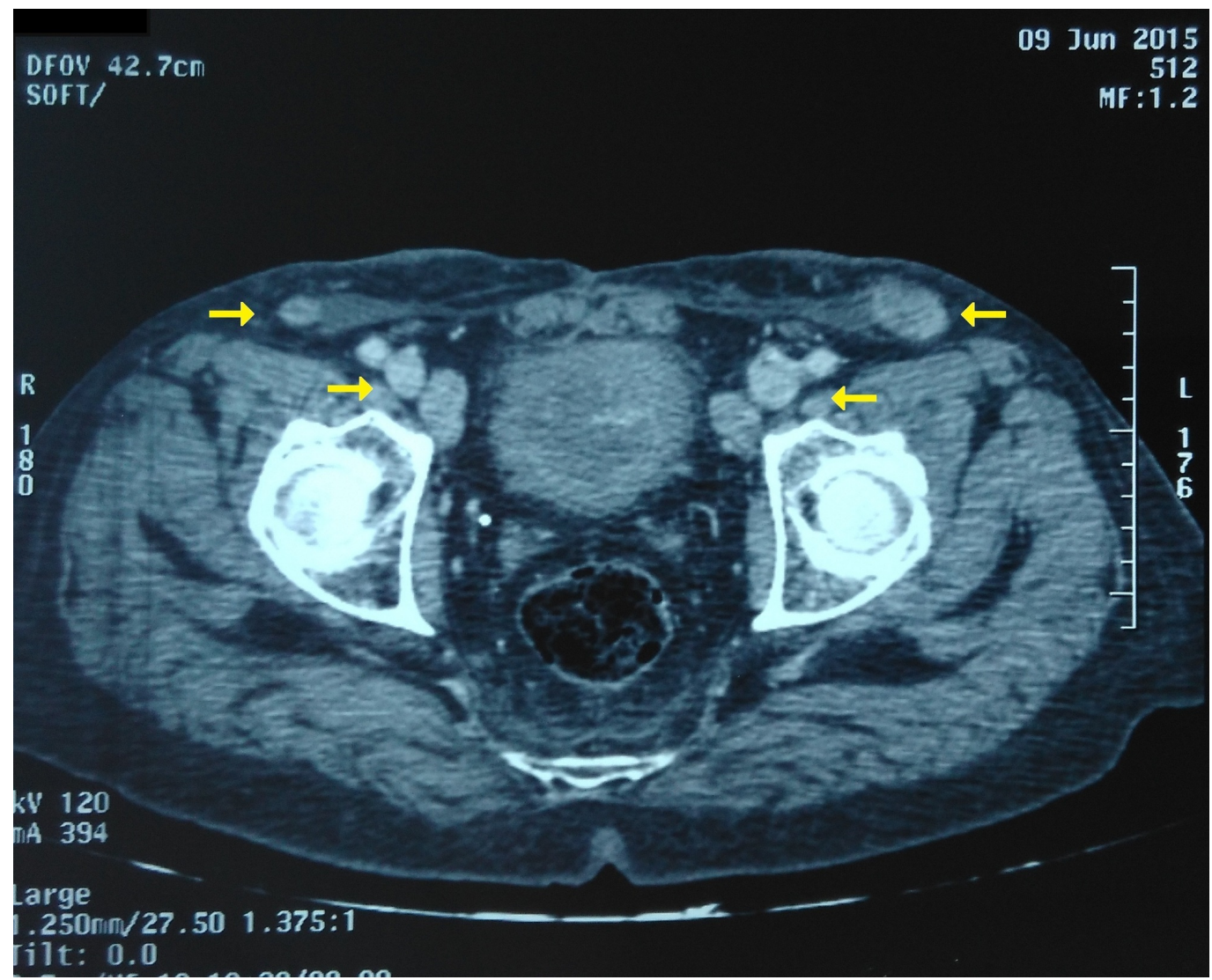

FIGURE 2: Axial section of CT scan showing bilateral iliac and inguinal lymph nodes (yellow arrows).

The patient only underwent an incomplete excision because the tumor was locally advanced in the perineum. The penis and testis weren't involved. Urine was drained by a cystostomy tube. Pathological examination of the surgical specimen concluded at a moderately differentiated squamous cell carcinoma (Figure 3). 


\section{Cureus}

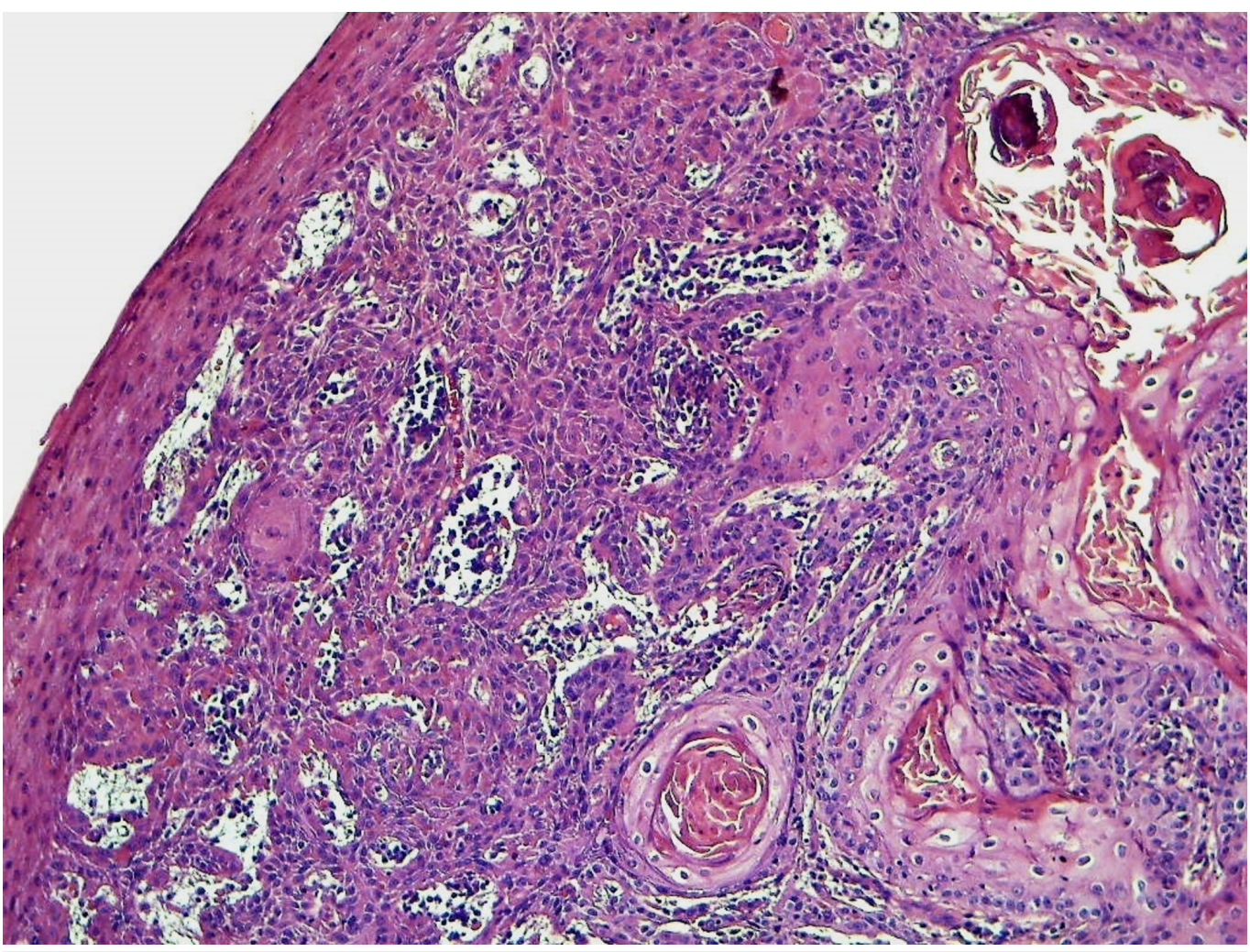

FIGURE 3: Invasive keratinizing squamous cell carcinoma developing from the epidermis (HE x 100)

Palliative radiotherapy has been discussed, but given the advanced age of the patient and his poor personal status, no further treatments were indicated. The wound took months to heal. The patient was followed regularly for 14 months until he was lost to follow up.

\section{Discussion}

Squamous cell carcinoma (SCC) is the most common histological type of scrotal cancer. Historically, SCC was the first malignancy to be linked directly to exposure to occupational carcinogens. In addition to soot, SCC has also been linked to exposure to tar, pith, different types of lubricating and cutting oils, creosotes, gas production, and paraffin wax pressing [1].

With better occupational health practices minimizing exposure at the workplace, the disease became very rare. In the modern era, the incidence of scrotal SCC is as low as 0.35 per 1,000,000 male persons per year [2]. Most cases are thought to result from poor hygiene and chronic irritation. More precisely it can be linked to radiation history, psoriasis treatment by Psoralenultraviolet light, and human papillomavirus (HPV) infection [3].

The patient we report here had a more than 20 years' chronic irritation of the scrotum by urine. It seems reasonable to hypothesize that chronic contact of the scrotal skin with urine because of the meatus position resulting in chronic inflammation might have contributed to the cancer development, as described in the only similar case in the literature that occurs in a 68-year-old man with a proximal uncorrected hypospadias [4].

By analogy, few case reports of SCC involving the urinary stoma as ureterocutaneostomy, suprapubic cystostomy, and Mitrofanoff ureterovesical stoma were described [5]. 


\section{Conclusions}

Through our case, we throw the light on the effect of chronic urinary irritation of the scrotum. Special attention must be paid to patients with mistreated urethral stricture or hypospadias resulting in a proximal meatus.

\section{Additional Information Disclosures}

Human subjects: Consent was obtained by all participants in this study. Conflicts of interest: In compliance with the ICMJE uniform disclosure form, all authors declare the following: Payment/services info: All authors have declared that no financial support was received from any organization for the submitted work. Financial relationships: All authors have declared that they have no financial relationships at present or within the previous three years with any organizations that might have an interest in the submitted work. Other relationships: All authors have declared that there are no other relationships or activities that could appear to have influenced the submitted work.

\section{References}

1. Zhu Y, Ye DW: Preneoplastic and primary scrotal cancer: updates on pathogenesis and diagnostic evaluation. Urol Clin North Am. 2016, 43:523-30. 10.1016/j.ucl.2016.06.013

2. Verhoeven RH, Louwman WJ, Koldewijn EL, Demeyere TB, Coebergh JW: Scrotal cancer: incidence, survival and second primary tumors in the Netherlands since 1989. Br J Cancer. 2010, 103:1462-6. 10.1038/sj.bjc.6605914

3. Azike JE: A review of the history, epidemiology and treatment of squamous cell carcinoma of the scrotum. Rare Tumors. 2009, 1:47-9. 10.4081/rt.2009.e17

4. Pomara G, Pomara S, Travaglini F, Maras L, Selli C: Verrucous scrotal carcinoma in a patient with hypospadias: is there a possible association?. Urology. 2003, 61:224. 10.1016/S00904295(02)02095-2

5. Reddy BN, Subhash M, Pilichowska M, Klauber: Primary squamous cell carcinoma arising from a cutaneous a ureterovesical stoma (modified Mitrofanoff): Case report and review of literature. Urology. 2017, 9:225-7. 10.1016/j.urology.2016.06.017 